Plate 2

Photomicrographs of kidney sections of ewes, stained with haematoxylin and Sudan IV, exposed with blue filter, peak transmission about $465 \mathrm{~m} \mu$.

I. Pre-service control

2. After roo days on adequate diet

3. High-plane, unstarved

4. Low-plane, unstarved

5. High-plane, starved for 6 days

6. Low-plane, starved for 6 days
Assessment of fat*

- ve

- ve

-ve

$+$

* For method of assessment see Table I.

\title{
The Energy Expenditure and Food Intake of Individual Men
}

\author{
By O. G. EDHOLM AND J. G. FLETCHER \\ Division of Human Physiology, National Institute for Medical Research, London \\ and ELSIE M. WIDDOWSON and R. A. MCCANCE \\ Medical Research Council Department of Experimental Medicine, University \\ of Cambridge
}

(Received 5 February I955)

Within the last 15 years an interest in the importance of calorie expenditure and its relationship to intake has begun to reassert itself after a long interval of time. Broadly speaking there have been two reasons for it: the first has been a desire to find out more about the mechanisms which relate intake to expenditure - what regulates appetite, in fact-and the second an interest in industrial and field physiology. The first detailed study of energy expenditure and dietary intake was made by Bedale (1922-3). Bedale measured the oxygen consumption of roo schoolchildren at twentyfive different activities and the time they spent on these activities. Wiehl (I944) investigated by a diary and interview technique the activities of high-school boys and girls in the United States over a 2-day period. These activities were listed under the headings of sleeping, sitting, and light, moderate and severe exercise, and the mean expenditure agreed very well with the intake, but the individual intakes varied from 50 to $190 \%$ of the expenditures. Keys (1945) criticized these findings as showing the fallacy of computing requirements in this way, and pointed out that individuals who were not rapidly gaining or losing weight must be in calorie balance. This is true, but they need not be in daily balance. Fox (1953) estimated the calorie expenditure and the food intake of members of a village in the Gambia over a period of a year. He measured the oxygen consumption at various tasks and recorded the time spent on the different occupations. Owing to a period of food shortage which coincided with the heavy farming work in preparation for the forthcoming harvest, calorie balance was only achieved over a matter of months, with corresponding losses and gains of weight. 
Lehmann (1953) described the expenditure of energy on a number of industrial occupations which had been subjected to close analysis, but unfortunately these studies took no account of the energy expenditure outside working hours. Passmore, Thomson \& Warnock (1952) made a balance sheet of the energy intake and expenditure of a small group of students under laboratory conditions, and obtained virtually exact agreement between the two over a period of I week. Garry, Passmore, Warnock \& Durnin (1955) made a study of coal miners by a combination of oxygen measurements, diary records and dietary observations, and obtained figures for the men's energy expenditure at their daily occupations and its relation to their calorie intakes in terms of food. Bransby (1954) collected records of the time spent by 152 industrial workers at their jobs and at various out-of-factory activities, and he also made a dietary survey on the individual men. Widdowson, Edholm \& McCance (1954) made a group survey of seventy-seven cadets at a military establishment. The total food intake was measured at each meal for a week and the expenditure of energy computed by means of a diary technique supplemented by a few direct measurements of oxygen consumption. The intake was found to be $3705 \mathrm{Cal}$./cadet/day and the expenditure $3420 \mathrm{Cal} /$ /cadet/day. This agreement was considered to be reasonably good, but it was felt that if the diary technique could be improved and if the necessary measurements of oxygen consumption could be made on a small group of men, their individual outputs of energy could be measured with sufficient accuracy from day to day to make it profitable to compare them closely with their individual intakes and so find out more about this important biological relationship.

\section{EXPERIMENTAL}

General. The investigations were made at the same establishment as before (Widdowson et al. 1954); the life of the place had changed little in the meantime. Twelve cadets were studied for a period of 2 weeks-from 29 June to 12 July 1953 . Six of them were intermediates in their second 6 months (nos $I-6)$, and six were juniors in their first 6 months (nos. $7^{-12}$ ). All belonged to the same unit and were selected after discussion with the unit commander as being similar in height, weight, athletic interests and training (Table $\mathrm{r}$ ).

Measurement of food and calorie intake. All the food eaten by each individual cadet was weighed every day for 2 weeks. The cadets sat at one table at the end of the large dining hall and three assistants were responsible for seeing that nothing was eaten that was not weighed. Most foods were provided in limited amounts, and these portions were weighed at a side table and their weights recorded before being handed to the cadet. Foods that were available in unlimited quantities, that is bread, potatoes and sometimes other vegetables, were weighed on spring balances which stood on the dining table; the cadets helped themselves to these foods and one of the assistants noted the weights and recorded them. All plate waste was weighed and subtracted from the weight of the portion served. The composition of cooked dishes was calculated as before from a knowledge of the raw ingredients and the method of cooking.

An assistant was present in the canteen whenever it was open and he recorded the 
amounts of all foods and drinks bought by each of the twelve cadets taking part in this investigation. The composition of these 'extras' was also calculated from a knowledge of their ingredients. The cadets themselves were responsible for keeping a record of any additional foods, e.g. chocolate and biscuits, which they ate during the fortnight of the investigation.

\section{Table I. Ages, weights and surface areas of the twelve subjects}

\begin{tabular}{|c|c|c|c|c|c|}
\hline \multirow{2}{*}{$\begin{array}{c}\text { Subject } \\
\text { no. }\end{array}$} & \multicolumn{2}{|c|}{ Age } & \multirow{2}{*}{$\begin{array}{c}\text { Weight } \\
(\mathrm{kg})\end{array}$} & \multirow{2}{*}{$\begin{array}{l}\text { Surface } \\
\text { area } \\
\left(\mathrm{m}^{2}\right)\end{array}$} & \multirow{2}{*}{$\begin{array}{l}\text { Height } \\
(\mathrm{cm})\end{array}$} \\
\hline & Years & Months & & & \\
\hline I & I9 & I & $68 \cdot 4$ & $\mathbf{r} \cdot 87$ & $r 80 \cdot 3$ \\
\hline 2 & 20 & 0 & $69 \cdot 4$ & $x \cdot 90$ & 184.2 \\
\hline 3 & 19 & Io & $67 \cdot 0$ & $\mathbf{r} 87$ & $182 \cdot 9$ \\
\hline 4 & 19 & 5 & $78 \cdot 8$ & $2 \cdot 08$ & 189.9 \\
\hline 5 & 20 & $\circ$ & $7 \times 5$ & $r \cdot 89$ & $179^{\circ} \mathrm{I}$ \\
\hline 6 & 20 & 9 & $8_{3} \cdot 8$ & $2 \cdot 14$ & $189 \cdot 9$ \\
\hline 7 & 18 & 9 & $67 \cdot 1$ & $I \cdot 84$ & $177^{-8}$ \\
\hline 8 & 19 & 4 & $68 \cdot 5$ & $\mathrm{I} \cdot 86$ & I79.I \\
\hline 9 & I9 & 4 & $62 \cdot 4$ & $\mathrm{I} \cdot 74$ & $172 \cdot 7$ \\
\hline Io & 19 & 8 & $76 \cdot 7$ & $2 \cdot 00$ & $184 \cdot 2$ \\
\hline II & 18 & 6 & $69 \cdot 3$ & $I \cdot 7 I$ & $172^{\circ} \mathrm{I}$ \\
\hline \multirow[t]{2}{*}{12} & 18 & II & 65.9 & $\mathrm{I} \cdot 85$ & $\times 8 \mathrm{I} \cdot 6$ \\
\hline & Mean I9 & $5^{\frac{1}{2}}$ & $70 \cdot 0$ & $r \cdot 89$ & $18 \mathrm{I} \cdot \mathrm{I}$ \\
\hline $\begin{array}{l}\text { First survey } \\
\text { gean of seventy- } \\
\text { seven cadets) }\end{array}$ & Mean I9 & 9 & 68 & $x \cdot 84$ & I 78 \\
\hline
\end{tabular}

The calorie, protein, fat, carbohydrate and alcohol intakes of the individual cadets were calculated from food tables (McCance \& Widdowson, $1946 a$ ), each of the $\mathrm{r}_{4}$ days being calculated separately.

Time study. The diary method used was similar to that employed by Garry et al. (1955) in their investigation of the calorie expenditure of the East Fife coal miners. Each cadet was issued with a diary form which covered $18 \mathrm{~h}$. It was collected at breakfast time, when a new form was issued. By a simple code it was possible for the subject to indicate, by one letter only in most instances, what he was doing at any particular minute. For certain activities it was not possible for the subject to do more than indicate the beginning and end of the time spent. Such activities included military parades, games and lectures, and for these the observers timed the various phases accurately with a stop-watch. A drill parade, for example, would be timed and shown to consist of so many minutes standing to attention, at ease, rifle drill and so on (Table 2). Since all the cadets in any one team would, in general, be attending the same parades, it was relatively easy to have a detailed observation of such activities. Metabolic determinations were made to cover as far as possible all phases of activity by the cadets. Many estimations were made on activities such as lying, sitting and standing, which covered the greater part of the day. From the diary sheets the time spent in the various activities each day was calculated, and the energy expenditure of a particular activity was entered on the form so that the energy expenditure involved for each activity could be calculated. Complex actions, e.g. a period of $2 \mathrm{~h}$ drill, were calculated on the basis of so many minutes of standing or other activities, and 
the calorie expenditure for standing, for rifle drill and so on was used to compute the total expenditure.

Metabolic measurements. Expired air was collected using Douglas bags and the Max Planck Institute (M.P.I.) calorimeter. A number of estimations were made serially on the same subjects with the M.P.I. calorimeter and Douglas bag. The M.P.I. calorimeter has already been fully described (Kofranyi \& Michaelis, 1940; Lehmann,

Table 2. Analysis of drill parade. Subject no. I

\begin{tabular}{|c|c|c|c|}
\hline \multirow[b]{2}{*}{ Activity } & \multirow{2}{*}{$\begin{array}{c}\text { Time } \\
\text { (A) }\end{array}$} & \multicolumn{2}{|c|}{ Calorie cost } \\
\hline & & $\begin{array}{l}\text { Cal./min } \\
\text { (B) }\end{array}$ & $\begin{array}{l}\text { Total (Cal.) } \\
(\mathrm{A}) \times(\mathrm{B})\end{array}$ \\
\hline Standing: at ease & 22 & $\mathrm{I} \cdot 78$ & $40 \cdot 35$ \\
\hline at attention & 27 & $2 \cdot 05$ & 89.07 \\
\hline Arms drill & 24 & $13 \cdot 20$ & 319.04 \\
\hline Dressing the ranks & IO & 3.08 & $32 \cdot 28$ \\
\hline Marching: quick & I 3 & 10.48 & $138 \cdot 34$ \\
\hline slow & 45 & $7 \cdot 86$ & $53 \cdot 06$ \\
\hline Total & 120 & $5 \cdot 57$ & $672 \cdot 14$ \\
\hline
\end{tabular}

Müller \& Spitzer, 1949-50; Orsini \& Passmore, I951; Müller \& Franz, I952). In order to overcome possible inaccuracies while learning the technique the first determinations made on the cadets were of energy expenditure during sitting, standing and lying, and the order of these was arranged in the form of a Latin square. The M.P.I. respirometers were calibrated at frequent intervals by passing air through a gasmeter at a constant rate and thence into the M.P.I. respirometer. Varying rates were used, and hence the constancy of the calibration factor was determined. When light activities were involved such as sitting, standing or lying, subjects used a conventional mouthpiece and a light Perspex valve holder. When heavier activities, such as cycling or games were involved, masks with inspiratory and expiratory valves were used instead. These masks were similar to the R.A.F. ' $H$ ' masks, with a dead space of about $250 \mathrm{ml}$. Masks were in general preferred by the subjects to mouthpieces when any active movement was involved.

Gas analysis. Five members of the team carried out gas analyses, four using the Haldane gas analysis apparatus and one the Scholander apparatus. The gas samples were transferred from the small rubber bags attached to the M.P.I. respirometer into glass sampling tubes at the site of the metabolic investigations. If Douglas bags were used, the volumes of gas in them were measured in the laboratory or on the site, and samples transferred to sampling tubes. Analyses were carried out within I-Io h after collection. On a number of occasions two samples of the same collection of expired air were obtained, and the analyses of these were carried out by different workers. The results of these analyses were used to check the accuracy of the individual analysts. All analyses were carried out in duplicate.

The duplicate analyses of one analyst gave results which indicated on the average 0.48 vol. \% less oxygen than those of the others; her results were discarded. Calculation of the calorie value of the oxygen consumed was made using Weir's (1949) technique. 
RESULTS

Intakes. Table 3 shows the mean intakes of calories, protein, fat, carbohydrate, alcohol, calcium and iron in this investigation and in the previous one (Widdowson et al. 1954). The proportions of the various dietary constituents were very similar to those found in the group investigation previously made at the same establishment,

Table 3. Composition of the average diet of the cadets in the present investigation and in the earlier one (Widdowson et al. 1954)

\begin{tabular}{lcc}
\multicolumn{1}{c}{ Item } & $\begin{array}{c}\text { Previous investigation } \\
\text { (mean for seventy- } \\
\text { seven cadets for } \\
\text { I week) }\end{array}$ & $\begin{array}{c}\text { Present investigation } \\
\text { (mean for twelve } \\
\text { cadets for } \\
\text { 2 weeks) }\end{array}$ \\
Calories (Cal./day) & 3705 & 3432 \\
Protein (g/day) & 104 & 99 \\
Fat (g/day) & 139 & 123 \\
Carbohydrate (g/day) & 509 & 488 \\
Alcohol (g/day) & 11 & 8 \\
Calcium (g/day) & $1 \cdot 28$ & $1 \cdot 14$ \\
Iron (mg/day) & $23 \cdot 7$ & $21 \cdot 0$
\end{tabular}

but all the amounts were a little less on the second occasion. This difference is entirely due to a reduction in the amount of food bought at the canteen and outside, for the average calorie intakes in the dining hall were almost identical in the two investigations (2527 and $2549 \mathrm{Cal}$. for the first and second surveys respectively). Seniors were included in the first investigation but not in the second; these had a special canteen of their own which served such foods as bacon and egg, baked beans on toast, sausages and chips, and when the results of the previous investigation were re-examined it was found that the seniors obtained on the average twice as many calories from the food they ate in their canteen as the intermediates and juniors obtained from theirs. The calories which the intermediates and juniors derived from food that they bought were very nearly the same in the two investigations ( 900 and 883 Cal. respectively), and their mean total calorie intakes were almost identical on the two occasions $(3427$ and 3432 Cal./day).

There is a suggestion that for some reason the metabolic observations slightly reduced the intake of food. Both groups ate a little less during the weeks when the expenditures were being measured. In the junior group the mean calorie intake was 3212 Cal. against 3469 , and this difference was statistically significant; the difference for the intermediates was not significant and no reason can be assigned to either of them.

Expenditures. The time spent on various activities and the calorie expenditure involved in these activities are shown in Fig. I. These results were in general similar to those obtained in the first survey, and the time and energy spent sitting and sleeping are again noteworthy. Since, however, the second survey was so much more complete it has been possible to dispense with a block for 'miscellaneous activities'. Much more time was spent 'standing' in the second survey and to a large extent accounted for the time previously assigned to 'miscellaneous activities'. Sitting did not take up quite 
so much of the total time as it did in the first survey; more time was spent in walking and less on cycling; in fact the cadets taking part did very little cycling in the second survey, for they lived in the main building which also housed the dining room, canteens and lecture theatres. In the first survey the sleeping quarters had been nearly half a mile away from lecture theatres and dining hall, and the cadets had had to cycle this distance repeatedly during the day.

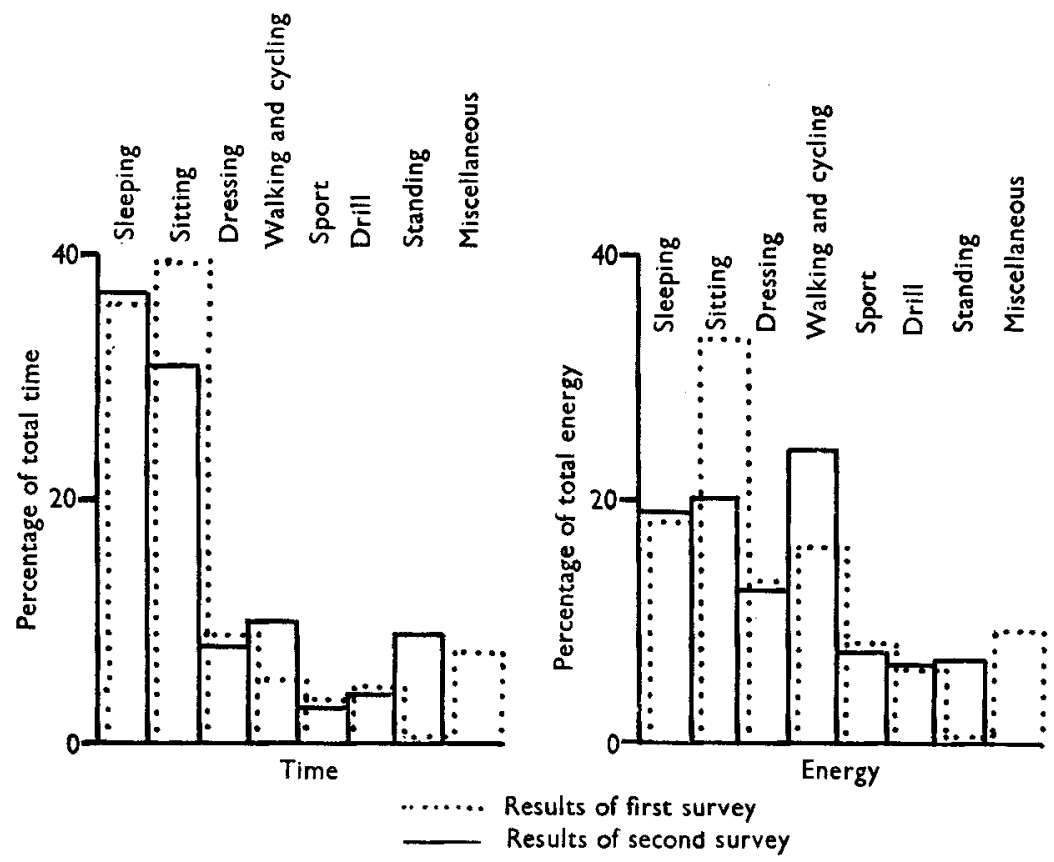

Fig. I. Percentage of time and energy spent by the cadets in various activities. The percentage of the total time ( 2 weeks) spent in any particular activity is shown on the left-hand side of the figure. On the right is shown the percentage of the total energy expenditure used in these activities. The results of the first survey (Widdowson et al. 1954) are given for comparison. The results of the two surveys are similar, but the column headed 'Miscellaneous' is absent from the second survey, as much more detailed information was obtained.

Tables 4-7 give the detailed results of the measured expenditure at various 'tasks'. Most of the figures are means of a number of tests made on the same subject. Since the establishment was a military one, a good deal of attention was devoted to drill. The way in which each figure is derived will be made clearer by reference to Table 2, which shows the calorie expenditure on various aspects of drill by one of the subjects and the times spent on them during the whole parade. Apart from their absolute values for future reference the figures shown in these tables have two main interests according to whether they are compared vertically or horizontally, Some points to be noted are perhaps: (1) The figure for lying was of the order of $\mathrm{I} \cdot 5 \mathrm{Cal} / \mathrm{min}$, so that these men would have required about $2200 \mathrm{Cal}$./day to prevent them from losing weight had they been kept in bed. This seems a reasonable estimate, but it may be a little high, for it has been shown (Courtice \& Douglas, 1935-6) that previous activity can maintain 
a higher output of energy at rest for several hours. (2) The vertical comparisons require little comment. The 'indoor' activities grouped themselves round about $2 \mathrm{Cal} / \mathrm{min}$, but dressing was a more active pursuit than this for most of these young men; it may be so for many other people for it is a task very often performed 'in a hurry'. Climbing

Table 4. Cost (Cal./min) of activities for individual subjects

\begin{tabular}{|c|c|c|c|c|c|c|c|}
\hline \multirow[b]{2}{*}{$\begin{array}{c}\text { Subject } \\
\text { no. }\end{array}$} & \multicolumn{7}{|c|}{ Activity } \\
\hline & Lying* & Sitting & Standingf & Marching§ & Running|| & $\begin{array}{l}\text { Stair- } \\
\text { climbing } 9\end{array}$ & Dressing** \\
\hline $\mathbf{I}$ & $I \cdot 55(2)$ & $I \cdot 49 \quad(3)$ & $x \cdot 78(2)$ & $6 \cdot 44(1)$ & $\begin{array}{l}\text { II }=\text { I } 5(\mathrm{I}) \\
8 \text { m.p.h. }\end{array}$ & - & - \\
\hline 2 & $I \cdot 3 I(3)$ & $I \cdot 62 \quad(2)$ & $I \cdot 78(3)$ & $6.02(2)$ & I $2 \cdot 33(2)$ & - & $3 \cdot 26(2)$ \\
\hline 3 & $I \cdot 7 \circ(3)$ & $1 \cdot 74 \quad(3)$ & $I \cdot 85(5)$ & $5.75(3)$ & $\begin{array}{l}7.5 \text { m.p.h. } \\
\text { 10.58 (2) } \\
7.5 \text { m.p.h. }\end{array}$ & 一 & - \\
\hline 4 & $I \cdot 44(4)$ & $I \cdot 6 I \quad(2)$ & $2 \cdot 19(3)$ & $7 \cdot 34(2)$ & $\begin{array}{c}\text { Io.56 (3) } \\
7.5 \text { m.p.h. }\end{array}$ & 一 & $4.98(\mathrm{I})$ \\
\hline 5 & $\mathrm{I} \cdot 86(3)$ & $2.06 \quad(3)$ & $2 \cdot 20(3)$ & $4 \cdot 42(2)$ & - & - & $4.88(x)$ \\
\hline 6 & $I \cdot 3 \circ(4)$ & $I \cdot 34$ & $I \cdot 43(3)$ & $6 \cdot 33(2)$ & $\begin{array}{c}\text { 13.32 (2) } \\
7.8 \text { m.p.h. }\end{array}$ & 一 & - \\
\hline 7 & $I \cdot 39(5)$ & I'59 (5) & $x \cdot 65(3)$ & $6 \cdot 33(2)$ & $\begin{array}{l}\text { Is.o (3) } \\
\text { IO-I I m.p.h. }\end{array}$ & $14.79(2)$ & 3.95 (2) \\
\hline 8 & $I \cdot 33(I)$ & $1 \cdot 47 \quad(3)$ & $I \cdot 85(4)$ & $4.53(4)$ & $\begin{array}{c}10.52(2) \\
6.5-7 \text { m.p.h. }\end{array}$ & $6 \cdot 12$ (I) & $3.56(2)$ \\
\hline 9 & $I \cdot 18(7)$ & $1 \cdot 46 \quad(4)$ & $I \cdot 6 I(8)$ & $5 \cdot 29(6)$ & 10.9 (2) & IO'I (I) & $3 \cdot 18(2)$ \\
\hline 10 & $r \cdot 62(3)$ & $r \cdot 65 \quad(2)$ & $I \cdot 90(4)$ & $7 \cdot 2 \mathrm{I}(\mathrm{I})$ & $\begin{array}{c}7.5 \text { m.p.h. } \\
\text { I3.14 (2) } \\
\text { 8-9 m.p.h. }\end{array}$ & - & $3 \cdot 63(2)$ \\
\hline I I & $\mathrm{I} \cdot 47(\mathrm{I})$ & $I \cdot 46 \quad(2)$ & $x \cdot 64(I)$ & $5.48(2)$ & II $8 \quad$ (2) & - & $3 \cdot 84(2)$ \\
\hline 12 & $I \cdot 60(4)$ & $I \cdot 74 \quad(4)$ & I'99(3) & $5 \cdot 64(2)$ & $\begin{array}{l}7.5 \text { m.p.h. } \\
\text { I } 3.66(2) \\
7.5 \text { m.p.h. }\end{array}$ & - & $4 \cdot 85(2)$ \\
\hline Mean & $I \cdot 48$ & $1 \cdot 60$ & $I \cdot 82$ & $\begin{array}{l}6.03 \\
\text { (excluding } \\
\text { no. 5) }\end{array}$ & $\begin{array}{c}\text { I } 167 \\
\text { (excluding } \\
\text { nos. } 7 \text { and ro). }\end{array}$ & $10 \cdot 30$ & 4.00 \\
\hline
\end{tabular}

Figures in parentheses give number of determinations.

* Not in basal state. Subjects lay for Io min before determination made.

$\uparrow$ Note small difference between lying and sitting.

\pm Standing at ease.

$\S$ Army pace, i.e. 3.4 m.p.h. Level surface. Subject no. 5 had an injured knee, walked at 2.8 m.p.h.

If At the double in uniform, level ground. Subjects nos. 7 and 10 ran at higher speeds.

S Steps 7 in. high. Time up and down forty-six steps: subject no. 7,48 sec., subject no. 8,67 sec., subject no. 9,45 sec.

** Trousers, tie, collar, shirt, anklets, boots, socks, belt removed and put on, and cycle repeated.

stairs and the outdoor sports demanded the expenditure of considerable energy and had they occupied more of the subjects' time would have made a great difference to their overall requirements. (3) Some of the tasks, e.g. drill, were more strenuous for all the men on some days than on others, but (4) there was a great difference in the efficiency with which any two men might perform the same task. Subject no. 4, for example, expended more energy on nearly all his activities than no. II, but this prodigality was not apparent when he lay down. Subject no. 9 lay, sat and stood with very little expenditure of energy, whereas no. 5 did just the reverse. These differences 
Table 5. Calorie cost (Cal./min) of kit cleaning

\begin{tabular}{|c|c|c|c|}
\hline \multirow[b]{2}{*}{$\begin{array}{c}\text { Subject } \\
\text { no. }\end{array}$} & \multicolumn{3}{|c|}{ Kit cleaning } \\
\hline & Ironing* & Polishing $†$ & $\begin{array}{c}\text { Rifle } \\
\text { cleaningt }\end{array}$ \\
\hline I & - & $2 \cdot I 6(2)$ & $3 \cdot 16(\mathrm{I})$ \\
\hline 2 & $3 \cdot 92(\mathrm{I})$ & $2 \cdot 66(\mathrm{I})$ & - \\
\hline 3 & - & $2 \cdot 24(t)$ & $2 \cdot 42(2)$ \\
\hline 4 & - & $2 \cdot 38(2)$ & - \\
\hline 5 & $3 \cdot 95(2)$ & $2 \cdot 45(3)$ & $2 \cdot 86(2)$ \\
\hline 6 & - & - & - \\
\hline 7 & $3.70(2)$ & $2 \cdot 3^{8(2)}$ & - \\
\hline 8 & - & - & $2 \cdot 68(2)$ \\
\hline 9 & - & - & $2 \cdot 30(4)$ \\
\hline Io & - & $2 \cdot 49$ (2) & - \\
\hline II & $4 \cdot 24(2)$ & - & $2 \cdot 7 x(1)$ \\
\hline 22 & $5 \cdot 16(2)$ & - & - \\
\hline Mean & $4 \cdot 20$ & $2: 40$ & $2 \cdot 70$ \\
\hline
\end{tabular}

Figures in parentheses give number of determinations.

* $5 \frac{1}{2} \mathrm{lb}$. electric iron. Standing and moving between table and board.

+ Sitting, polishing leather, buttons and other parts of kit.

$\ddagger$ Sitting two-thirds of the time, standing one-third.

Table 6. Calorie cost (Cal./min) of games and sports

\begin{tabular}{|c|c|c|c|c|c|c|c|c|}
\hline \multirow[b]{2}{*}{$\begin{array}{l}\text { Subject } \\
\text { no. }\end{array}$} & \multicolumn{3}{|c|}{ Cricket } & \multirow[b]{2}{*}{ Squash } & \multirow[b]{2}{*}{ Tennis } & \multirow[b]{2}{*}{ Cyclingt } & \multirow[b]{2}{*}{$\begin{array}{l}\text { Motor } \\
\text { cycling } \$\end{array}$} & \multirow[b]{2}{*}{ Driving $\S$} \\
\hline & Archery & Batting* & Bowling* & & & & & \\
\hline I & $4.77(\mathrm{I})$ & - & - & - & $6.43(I)$ & $7 \cdot 41(2)$ & - & 一 \\
\hline 2 & $5.71(2)$ & 一 & 一 & - & $6.87(2)$ & $\begin{array}{c}6.17(2) \\
\text { I I-12 m.p.h. }\end{array}$ & - & - \\
\hline 3 & - & $6.02(2)$ & $6 \cdot 7 \circ(2)$ & - & - & $\begin{array}{l}7.55(2) \\
12 \mathrm{mp} . \mathrm{h} .\end{array}$ & - & - \\
\hline 4 & $一$ & $9^{-86(2)}$ & $7 \cdot 02(2)$ & - & - & - & - & - \\
\hline 5 & 一 & - & - & 一 & 一 & $\begin{array}{l}8 \cdot 42(2) \\
\text { I0 m.p.h. }\end{array}$ & - & $一$ \\
\hline 6 & - & $9 \cdot 22(2)$ & $9 \cdot 13(2)$ & - & $5 \cdot 69(2)$ & $\begin{array}{l}7 \cdot 91(2) \\
12 \text { m.p.h. }\end{array}$ & - & - \\
\hline 7 & - & - & 一 & I $1 \cdot 85(3)$ & $7 \cdot 24(2)$ & $\begin{array}{c}\text { 15.77(r) } \\
\text { r } 8 \text { m.p.h. } \\
8 \cdot 14(\mathrm{I}) \\
\text { 12-1 } 3 \text { m.p.h. }\end{array}$ & - & - \\
\hline 8 & 一 & $6 \cdot 89(2)$ & $9 \cdot 15(2)$ & $9.05(4)$ & - & - & $2 \cdot 14(2)$ & $2 \cdot 45(2)$ \\
\hline 9 & - & - & - & $8 \cdot 51(2)$ & 一 & $\begin{array}{c}6 \cdot 29(2) \\
12 \text { m.p.h. }\end{array}$ & $2 \cdot 87(2)$ & $3 \cdot 67(2)$ \\
\hline 10 & - & - & - & II 46 (2) & $8 \cdot 48(2)$ & $8 \cdot 6$ I (2) & - & - \\
\hline I I & 一 & - & - & $1 \mathrm{I} \cdot 20(2)$ & $7 \cdot 78(2)$ & $\begin{array}{c}\text { 12-13 m.p.h. } \\
8 \cdot \text { I6 (2) } \\
\text { I2 m.p.h. }\end{array}$ & $3 \cdot 46(2)$ & $4 \cdot 06(2)$ \\
\hline $\mathrm{r} 2$ & - & - & - & 9.02 (I) & $7 \cdot 43(2)$ & $\begin{array}{c}9 \cdot 28(2) \\
\text { I3 m.p.h. }\end{array}$ & - & - \\
\hline Mean & $5 \cdot 24$ & $8 \cdot 0$ & $8 \cdot 0$ & IO. 18 & $7 \cdot 13$ & $\begin{array}{c}7 \cdot 72 \\
\mathrm{r2-r} 3 \text { m.p.h. }\end{array}$ & $2 \cdot 82$ & $3 \cdot 3^{8}$ \\
\hline
\end{tabular}

Figures in parentheses give number of determinations.

* Batting and bowling at the nets. Batsmen ran between wickets twice every six balls.

+ Subject no. 5 injured knee, first value on subject no. 7 at much faster speed. Both omitted from mean. Runs made on nearly level road.

† Heavy army motor cycle on level ground.

$\S$ is cwt. army truck. Driving on level ground. 


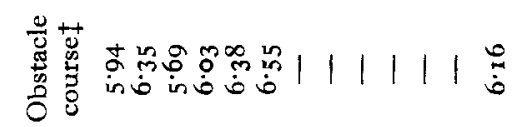

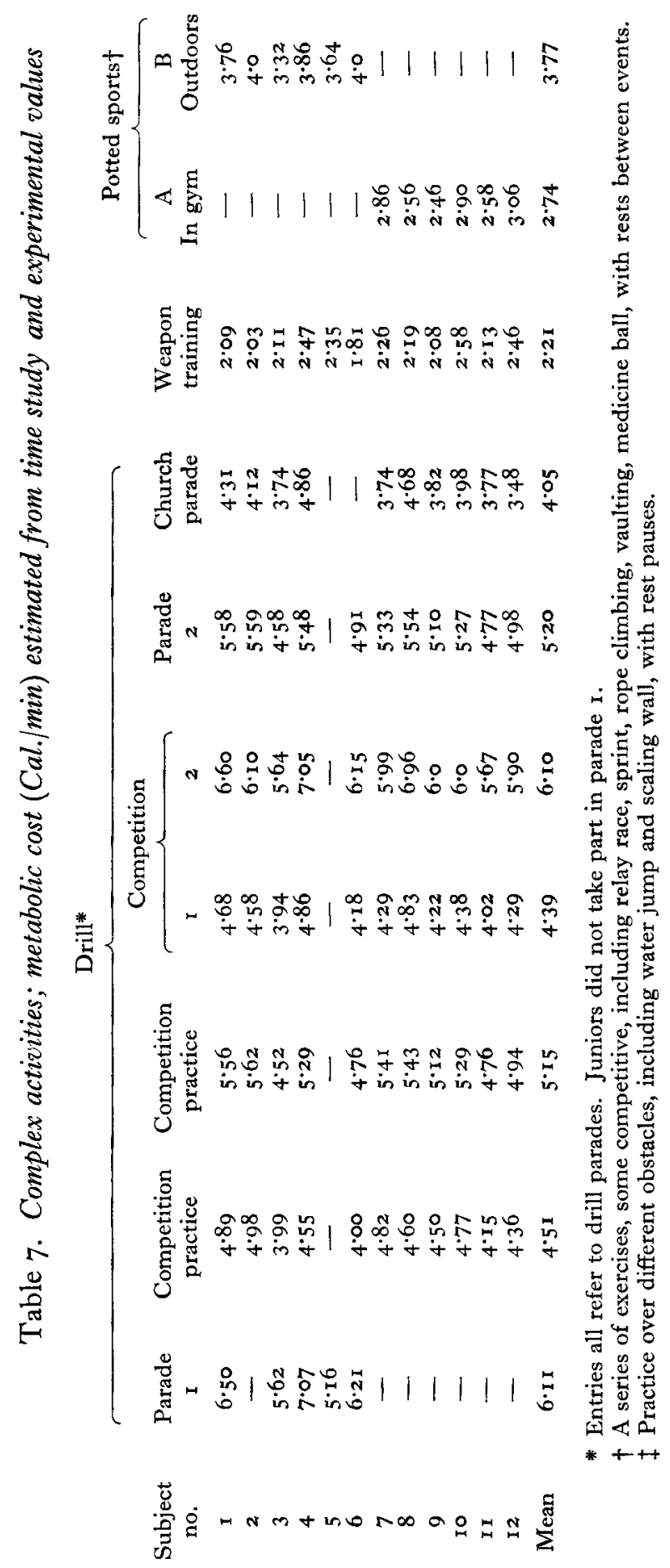


were consistent from day to day, for the men's expenditure of energy on the quantitatively important tasks was often measured a number of times although the separate figures have not been given in Table 4 . There was therefore a real spread in the amounts of energy expended on some of these tasks even by men who appeared very similar in all outward respects.

Energy balances. Each person's daily intake and expenditure of calories is shown in Tables 8 and 9, together with the weekly means for the individuals, the daily and weekly means for the intermediate and junior groups and the daily and weekly means for both groups together. The mean expenditure for the twelve cadets over the whole fortnight was very close to that of the intake, and the same is true of the means for the groups of intermediates and juniors. In spite of the homogeneous nature of the groups and of their activities, the individual intakes differed by over $1000 \mathrm{Cal}$./day, even when averaged over 14 days. Greater variability than this has usually been found by those who have investigated less homogeneous groups of men, women or children (Widdowson, 1936, 1947; Widdowson \& McCance, 1936), and their reality becomes more and more certain as the methods of measurement have been improved. The individual intakes were also highly variable from day to day, and this again was confirmation of previous findings. As often as not these intakes were far from being in daily or even in weekly or fortnightly balances with the expenditures. Subject no. 6, for example, had an intake of 4469 Cal. on 6 July and an expenditure of only 2605, and no. 4's expenditure exceeded his intake by $645 \mathrm{Cal} /$ /day over the whole fortnight. There is a particularly marked discrepancy between intake and expenditure on Thursday, 9 July, when there was a drill competition. The energy expenditure of the cadets was individually higher than on any other day or equal to the highest level, but the intake on this day was much lower than the average for the whole fortnight. There is a mean difference of ${ }_{1027} \mathrm{Cal}$. between expenditure and intake. The food eaten in the mess was slightly above average, but only one-third of the normal amount was bought in the canteen. This may have been due, in part, to fatigue, and to less time being available to visit the canteen.

The daily intakes have been plotted against the expenditure in Fig. 2, and these differences seem much too large to be accounted for by experimental errors, which can hardly have been consistently in one direction or the other since the means for the intakes and expenditures agree so well. They must be accepted as real, and the men's changes in weight substantiate this, for although the subjects were not weighed at the beginning and end of the investigations owing to the difficulty of interpreting changes in weight over short periods of time, the routine determinations made every 4 months indicated that the weights of eleven out of the twelve men moved in the direction to be expected from their energy balances.

\section{DISCUSSION}

Since individual food studies were first made, it has always been a problem why two people of the same age and appearance and with similar occupations were so often found to have widely different calorie intakes. Widdowson (1947), for example, found that at every age between $I$ and 18 years it was possible to find one child in a group 


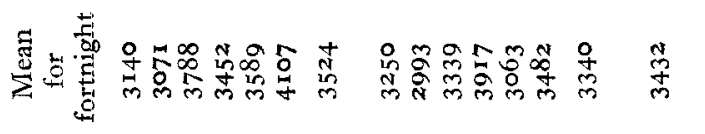

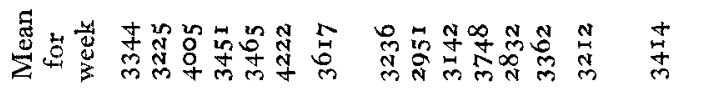

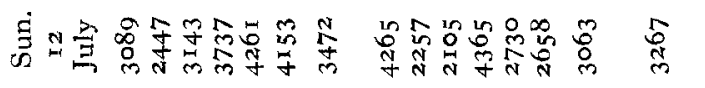

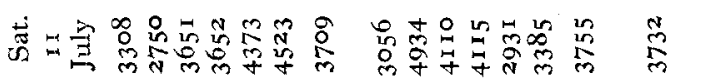

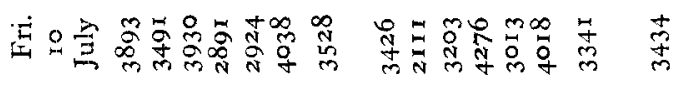

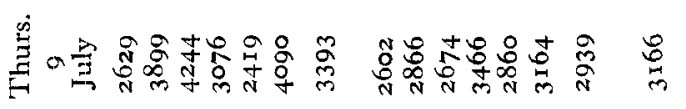

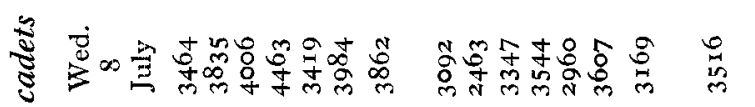
$\approx$

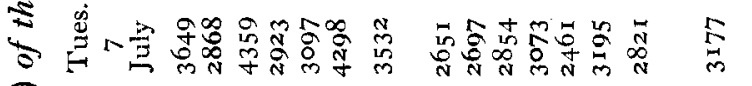

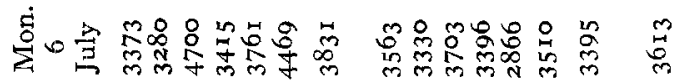

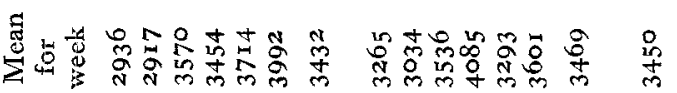
妾 密

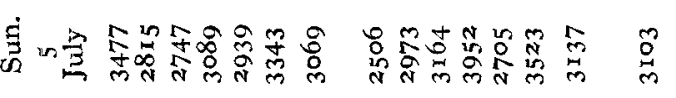

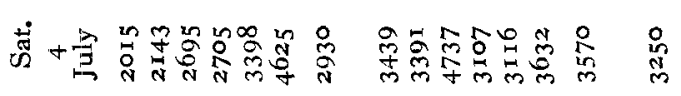
离 更

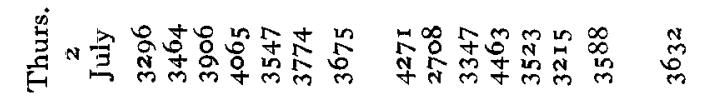

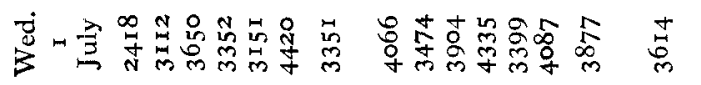

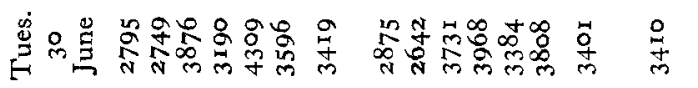

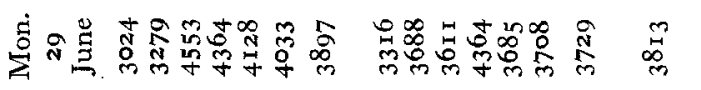

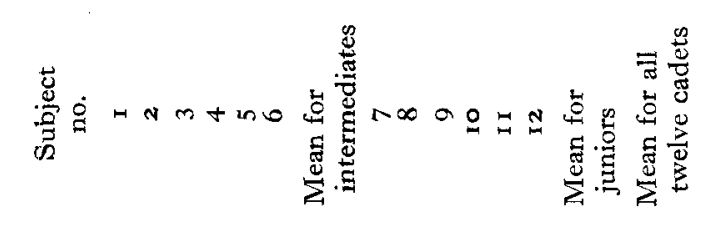

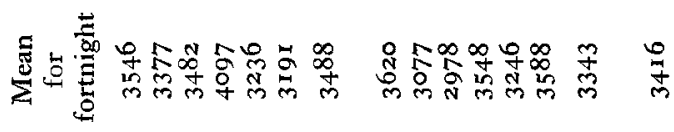

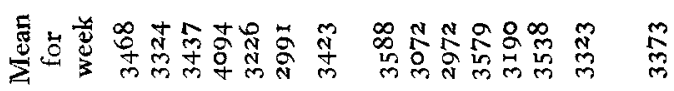

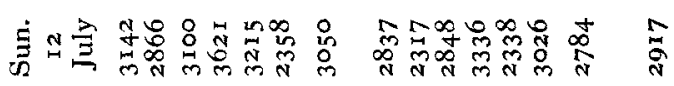

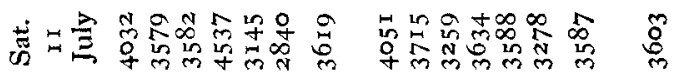

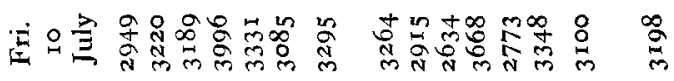

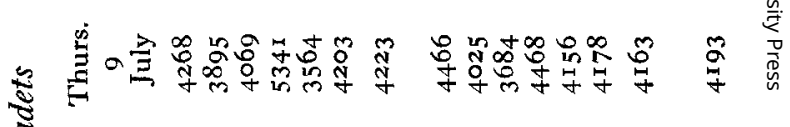

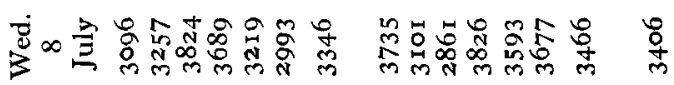

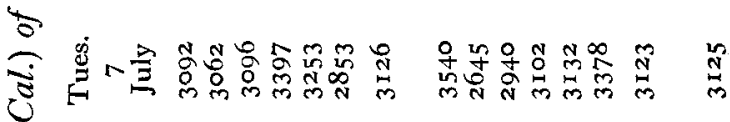

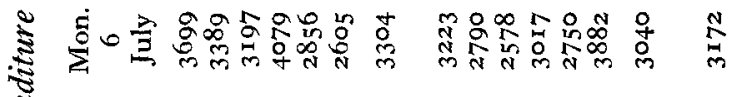

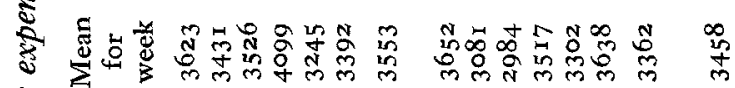

so

(ิ)

है

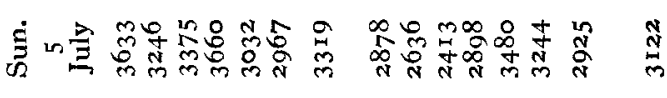

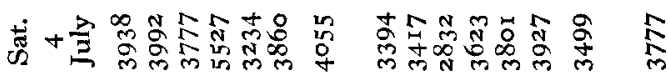
$\sigma$

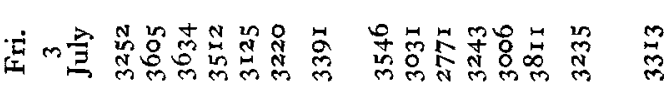

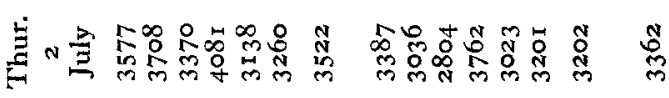

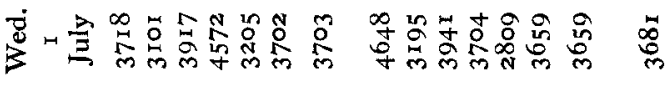

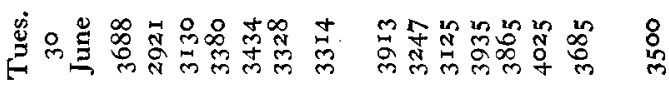

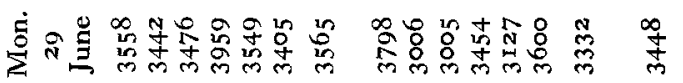


of twenty of the same sex who was eating nearly, if not quite, twice as much as another, and that these differences persisted if the two children were compared a second time. Differential changes in weight have not been found to be a complete solution, and it has been felt by most people that the differences between the intakes of food must originate in differences in the expenditure of energy. This study has shown that this is very probably so, for it has demonstrated that men may expend remarkably different

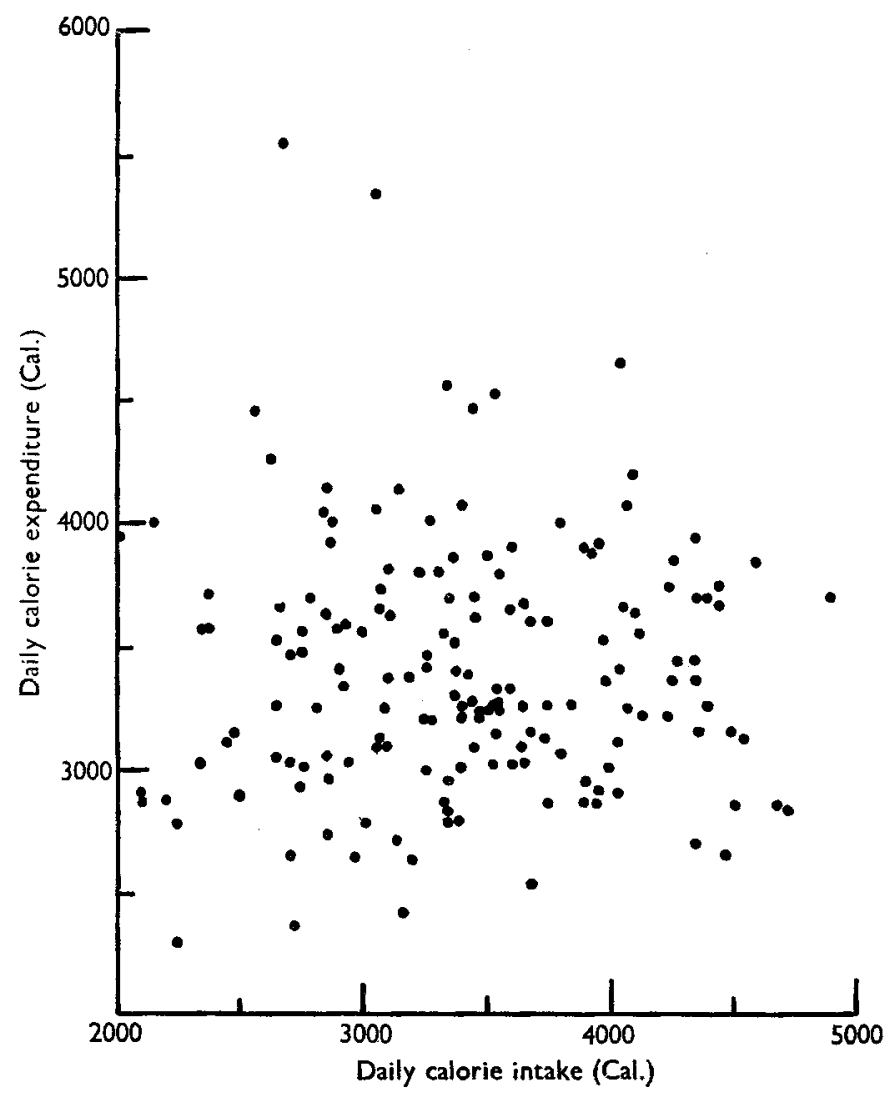

Fig. 2. Individual daily calorie intake and expenditure of the cadets. Daily individual food intake plotted against daily individual expenditure. Note the complete scatter of the results and the absence of any correlation.

amounts of energy in performing the same task. If one man can walk, sit and lie with half to two-thirds the energy expenditure of another, he will clearly require to eat much less food unless his occupation is a very different one and his hobbies equally so.

The expenditure of energy as dictated by circumstances and personal efficiency must create the demand for food, but how quickly and closely need the supply conform to the demand? In some animals, e.g rats and mice, the correlation is rapid and exact (Adolph, 1947; Kennedy, 1950; McCance, $1953 a, b$ ). Little is known quantitatively, however, about it in man, but here again the present experiments have been a help. There was no correlation between the expenditures and intakes of individuals (Fig. 2) 
on the same day or between the means for the expenditures and intakes on the same day, but there was a significant correlation between the mean daily expenditure and the mean daily intake 2 days later $(P=0.02)$. These findings are illustrated in Fig. 3 . Thus the intake of food tended to be low on days when the expenditure was very high and the deficit was made good some 2 days later. A much wider but equally spontaneous departure in the opposite direction from a person's customary plane of nutrition and a very belated correction was described by McCance \& Widdowson (1946b). What controls this apparently simple banking and credit system is really quite unknown, but the mechanism is clearly the same one which made the African farmers recoup their nutritional debts when the new harvest came in (Fox, I953), and German men whose

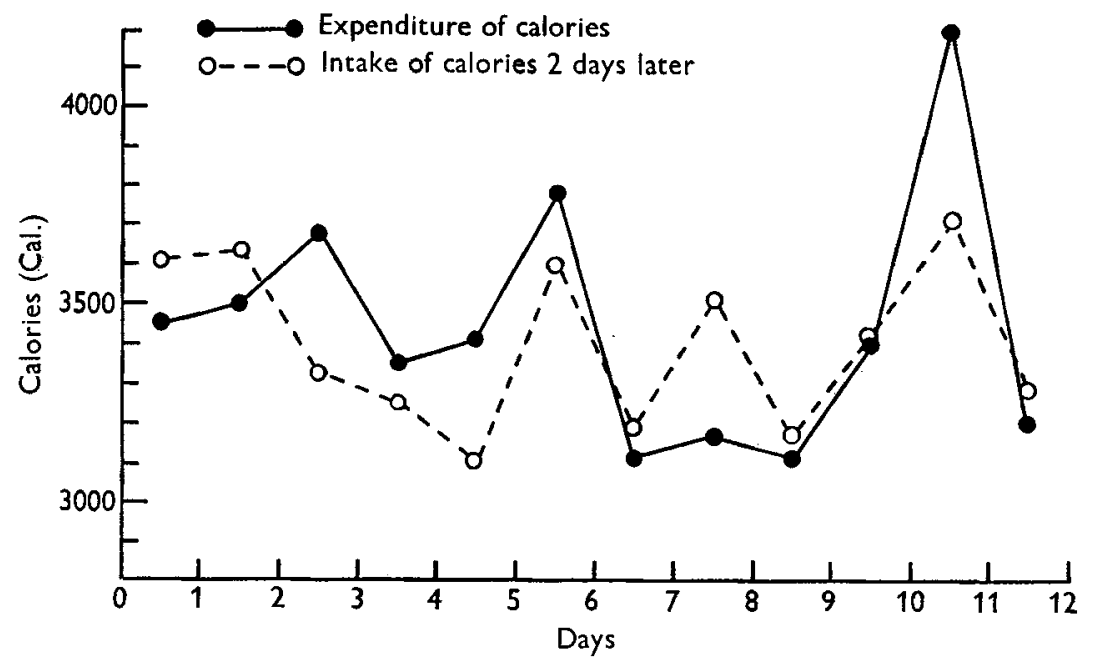

Fig. 3. Relationship between calorie expenditure and intake of the cadets. There is close agreement between the two plots indicating that daily intake of food is affected by the degree of activity 2 days previously.

intakes had been forcibly restricted in $1945^{-6}$, eat enough food to provide themselves with $6000 \mathrm{Cal}$./day for weeks on end when they were given the chance (Widdowson, 195I).

It is difficult to see how this belated adjustment of the intake of food to correct for an expenditure of energy incurred days, weeks or months before can be adequately explained by any theory which relates the sensations of appetite and hunger solely to the level of some metabolite such as glucose in the plasma or even in some specialized cellular sense organ (Mayer, Vitale \& Bates, 1951).

To the world at large the amount of energy expended by military cadets in batting at the nets or ironing may not seem very important, but when a sufficient number of the activities to which men and women devote themselves has been investigated it will be possible to compile them into a complete set of tables, just as the composition of foods has been tabulated. A careful time and diary record will then enable the energy expenditure of a homogeneous group to be investigated with a degree of accuracy which will be quite sufficient for many purposes. Owing to the differences that may 
exist between any two people in the energy they expend on the same basal 'activities', individual records will always have to be treated with reserve. The diary technique, however, if conscientiously carried out, will nevertheless provide valuable information about details of the average calorie expenditure, show how time is spent and what are the major activities of mankind. In the surveys so far carried out the time spent sitting has varied from $8 \frac{3}{4}$ to $10 \frac{3}{4} \mathrm{~h} /$ day and the time lying down has been of the same order (Table Io). It looks as though man should be regarded now, if not in the past, as predominantly a sedentary rather than an upright animal.

Table Io. Comparison of times spent per 24 h lying, sitting and standing by persons in different occupations

Subjects and reference
Mine workers (Garry et al. I955)
Clerks (Garry et al. r955)
Cadets-first survey (Widdowson et al.
I954)
Cadets-present survey
Schoolboys (Wiehl, I944)
Factory workers* (Bransby, 1954)

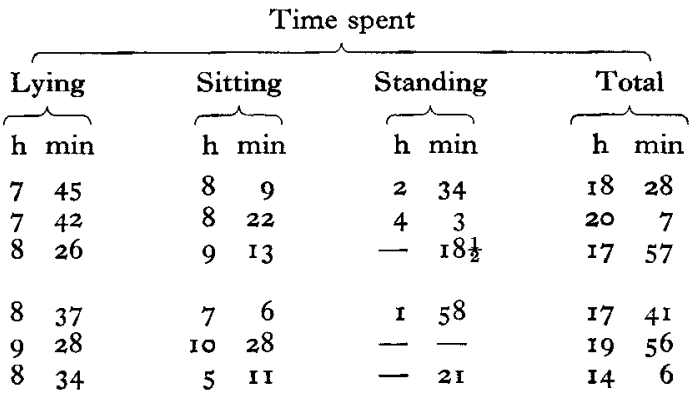

* Excluding working hours, which totalled $6 \mathrm{~h} 42 \mathrm{~min} /$ day.

\section{SUMMARY}

I. The individual expenditures of energy in a homogeneous group of twelve young men, cadets in a training establishment of the armed forces, were investigated daily for a fortnight by direct measurement coupled with an exact diary and timing technique. The expenditure varied widely from day to day.

2. The individual food intakes were also measured daily and varied equally widely.

3. The weekly and fortnightly balances between the two agreed when they were averaged, but there was no correlation between the mean expenditure on any one day and the intake on that day.

4. There was a correlation between the mean expenditure on one day and the intake 2 days later.

5. The energy expended on any one task, particularly a basal one such as sitting, lying or standing, often varied very much from one man to the next.

6. The energy expended by a number of men on tasks has been given in detail for future reference.

The dietary survey was carried out by Mrs L. A. Strangeways, Mr J. W. T. Dickerson and Mr L. A. R. Luff, and we thank them for all their help.

The energy expenditure survey required the assistance of a large team including Major J. M. Adam, Dr W. T. C. Berry, Mr L. M. Croton, Miss Pamela Dean, Dr J. V. G. Durnin, Mr A. G. Edwards, Miss Elizabeth Irving, Mr A. Kerr, Dr A. H. Kitchin, Dr K. Mahadeva, Mr A. Strachan and Mr W. G. Wilson Dickson. The 
inquiry could not have been made without their energetic and unstinting work, and we are greatly indebted to them.

Finally, we gratefully acknowledge the whole-hearted co-operation of the subjects and staff of the establishment concerned.

\section{REFERENCES}

Adolph, E. F. (1947). Amer. F. Physiol. 15x, г п.

Bedale, E. M. (1922-3). Proc. Roy. Soc. B, 94, 368.

Bransby, E. R. (1954). Brit. F. Nutr. 8, 100.

Courtice, F. C. \& Douglas, C. G. (1935-6). Proc. roy. Soc. B, 119, 381.

Fox, R. H. (1953). A study of energy expenditure of Africans engaged in various rural activities. Ph.D. Thesis, University of London.

Garry, R. D., Passmore, R., Warnock, G. M. \& Durnin, J. V. G. A. (1955). Spec. Rep. Ser. med. Res. Coun., Lond., no. 289.

Kennedy, G. C. (1950). Proc. roy. Soc. B, 137, 535.

Keys, A. (1945). F. Nutr. 29, 8I.

Kofranyi, E. \& Michaelis, H. F. (1940). Arbeitsphysiologie, II, I48.

Lehmann, G. (1953). Praktische Arbeitsphysiologie. Stuttgart: Georg. Thieme.

Lehmann, G., Müller, E. A. \& Spitzer, H. (1949-50). Arbeitsphysiologie, 14, I66.

McCance, R. A. (1953a). Lancet, 265, 685.

McCance, R. A. (1953b). Lancet, 265, 739.

McCance, R. A. \& Widdowson, E. M. (1946a). Spec. Rep. Ser. med. Res. Coun., Lond., no. 235, 2 nd ed.

McCance, R. A. \& Widdowson, E. M. (1946b). Spec. Rep. Ser. med. Res. Coun., Lond., no. 254.

Mayer, J., Vitale, J. J. \& Bates, M. W. (1951). Nature, Lond., r67, 562.

Müller, E. A. \& Franz, H. (1952). Arbeitsphysiologie, 14, 499.

Orsini, D. \& Passmore, R. (195 I). F. Physiol. 115, 95.

Passmore, R., Thomson, J. G. \& Warnock, G. M. (1952). Brit. f. Nutr. 6, 253.

Weir, J. B. de V. (1949). F. Physiol. xo9, r.

Widdowson, E. M. (1936). F. Hyg., Camb., 36, 269.

Widdowson, E. M. (1947). Spec. Rep. Ser. med. Res. Coun., Lond., no. 257.

Widdowson, E. M. (I95I). In Spec. Rep. Ser. med. Res. Coun., Lond., no. 275, p. 313 .

Widdowson, E. M., Edholm, O. G. \& McCance, R. A. (1954). Brit. F. Nutr. 8, 147.

Widdowson, E. M. \& McCance, R. A. (1936). F. Hyg., Camb., 36, 293.

Wiehl, D. G. (x944). Milbank mem. Fd quart. Bull. 22, 5. 